\title{
A NURSERY BUILDING AS A SPACE WITH VARIABLE FILLING IN ADAPTATION TO CURRENT NEEDS. IMPORTING AND INTERACTING UNITS
}

\author{
BUDYNEK ŻŁOBKA JAKO TŁO O ZMIENNYM WYPEŁNIENIU \\ W ADAPTACJI DO AKTUALNYCH POTRZEB. \\ JEDNOSTKI IMPORTUJACEE I ODDZIAŁYWUJĄCE NA SIEBIE
}

\author{
Paweł Szumielewicz \\ mgr. inż. arch. \\ Author's Orcid number: 0000-0002-4049-9905
}

SSC ARCHITEKCI

\begin{abstract}
Steve Jobs said that future should not be sought in official and main trends in the development of technical thought but in niche projects, experimental solutions that are not a part of "mainstream"; in ideas that are not obvious and seem absurd or illogical at first glance. Do the wish to prove that the impossible is within our reach let the design conditions change and adjust the direction of creative thinking so that they meet the expectations of clients and inverstors. The purpose of this paper is to attract attention to the necessity of changing the way nursery buildings are perceived and imagined - as space limited by permanent architectural barriers in which typical processes of cyclical character and didactic activities in linear schemes occur.
\end{abstract}

Key words: change, didactic activities, future, nursery building.

\section{STRESZCZENIE}

Steve Jobs powiedział, iż przyszłości nie należy szukać w oficjalnych i głównych nurtach rozwoju myśli technicznej lecz w niszowych projektach, rozwiązaniach eksperymentalnych będących poza tzw. „mainstreamem”. W zakamarkach i wydających się na pierwszy rzut oka absurdach oraz niedorzecznościach. Czy chęć udowodnienia, iż niemożliwe jednak jest w naszym zasięgu pozwoli na zmianę uwarunkowań projektowych i zmieni kierunek myśli kreatywnych w celu zaspakajania oczekiwań użytkowników i inwestorów. Celem niniejszego opracowania jest zwrócenie uwagi na konieczność zmiany odbioru i wyobrażenia, w powszechnej świadomości, budynku żłobka jako wydzielonej przestrzeń ograniczonej przegrodami stałymi, w której zachodzą typowe procesy o charakterze cyklicznym oraz działania dydaktyczne w liniowych schematach.

Słowa kluczowe: budynek żłobka, dydaktyka, przyszłość, zmiana. 


\section{INTRODUCTION}

Nursery building might be a place of uncoventional technical solutions and a place where such original projects affect children's development directly. It might be a space where developmental stages and the stimulation of perception are supported by advanced technology. Non-invasive technical solutions always ready for new functions adjusted to children's realistic, individual needs and their exploration of the environment. Elements that support natural curiosity and do not disturb free cognitive fun. Not only does socialization, balanced stimulation of personal development happen in a nursery but also parent support projects are realized. A nursery becomes an openspace workplace for both parents and children. Looking for an answer to the question of how a nursery turns into a place resembling a family in its organization one ought to refer to the theoretical point of view that highlights the fact that adults seek to create balanced relationships with children (Telka 2009 p.47). An adult is always approachable, ready to perform activities that support a child whenever he or she experiences difficulties realizing a specific task or activities that discourage negative behaviors. Actions taken by adults lead to so-called good favorable atmosphere (Telka 2009 p.45). Mutual relations that occur - create space with components such as: functional patterns (playing, education), repetitive actions (meals, hygiene) and the presence of adults (caregivers, parents). On one hand it is a structure that can be characterized as one with cyclical and repetitive performances and on the other - one that is very dynamic and constantly experiences variable processes at the same time. Concurrently - it generates and introduces safe constraints to creativity, curiosity and autonomy. Repetitiveness develops order and a conscious approach to the existing environment. The dynamic of spontaneity - autonomic decisions concerning particular goals - gives a chance to free and protected exploration of the surroundings. Communication, functions and activities performed by participants and forms created as a result of relations between participants are a factor that connects all the elements.

\section{SPACE}

Space in an object is organized by the presence of vertical and horizontal partitions dividing and separating it from the bigger environmental context into smaller parts. The act of partitioning is based on human experience and connected with the development of construction technology. Partitions might be considered a part of basic needs related to the feeling of safety according to A. Maslow's hierarchy of needs (Hierarchy of needs 1943). Thanks to partitioning it is possible to hide from external danger, be safe and not dependent on changeable weather conditions. Space, having been partitoned, creates the feeling of safety and survival. With time - partitions have become factors generating specific functions and every day activities but they still strongly connect humans with their surroundings. Thanks to constant development and a need of a better and more comfortable life - numerous connections to the natural environment were minimized. Satisfying new needs and meeting expectations has become a driving force for dynamic technological growth and a change in the perception of a human individual in an environment. Climate change, being a result of intense development of industry, farming, uncontrolled urbanization and mass tourism has become a turning point in the way human development is perceived and what influence it has on the environment (Myga-Piątek et al. 2009 p.37). The issues mentined above have modified the approach in scientific papers to one that is meant to improve current industrial solutions taking into consideration environmental protection but also minimizing human influence on the surroundings by introducing substitutes of physical presence in particular locations.

\section{OFFERS}

The way partitions are perceived by users together with their exploitation in order to perform particular tasks and satisfying varying needs introduces new elements with unconventional components. The research conducted between 2011 and 2012 in Poland as a part of the project entitled „A Polish adaptation of psychometric tools to diagnose the quality of the physical and social environment of children between the ages of 6 and 36 months old" (Hornowska et al. 2014 p.111-132) indicates the existence of addidtional aspects of the role of the enironment in child development. 
The main results of the research show that changes in needs of caregivers' presence and accessibility appear together with it: the child's natural need to be able to explore the environment independently, which increases with age, plays an extremely important role in the child's development, influencing the shape of his or her physical, cognitive and personality-related characteristics (Harnowska et al. 2014 p.134). The research concerned, among others, the connection between the diverse environment in which a child functions and the level of his or her development but also specified what elements of the surroundings are crucial to such development in early stages of childhood. The issues that have been mentioned are a part of most important research concerning the matter of exploring the environment by children, for whom the process of exploration itself becomes the vital part of activity. Constant exploration and experimenting with the usage of different objects is an integral part of child development. According to Gibson's theory, the knowledge that a child has about the surroundings is based on individual exploration (Gibson 1988 p.7). Meanwhile - the cognitive processes are analyzed as the relations between the working element and the actual surroundings that the element exists in. Thus - „offers”, i.e. multi-path processes or structural elements have the possibility to influence child development. Not only can toys be treated as offers but it is also common to consider spatial and cubature objects e.g. stairs, doors, etc. as such (fig. 1, 2).

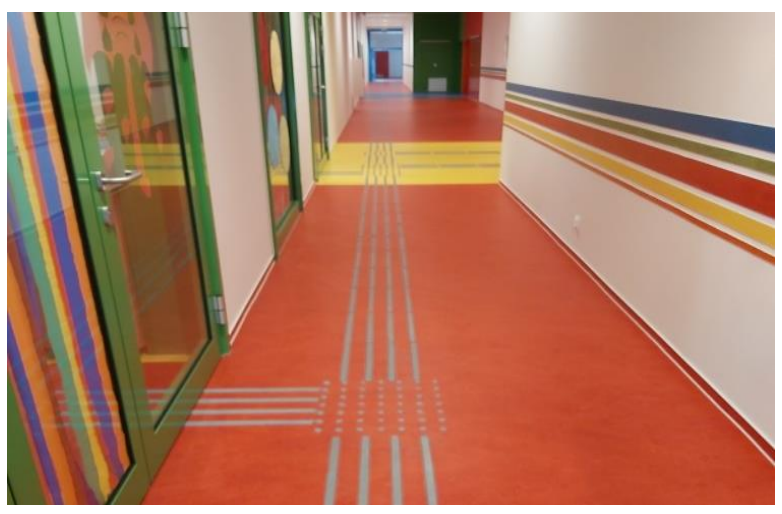

Fig. 1. Offers - the representation of the floor and the walls. Source: author.

Ryc. 1. Oferty - rysunek posadzki i ścian. Źródło: autor

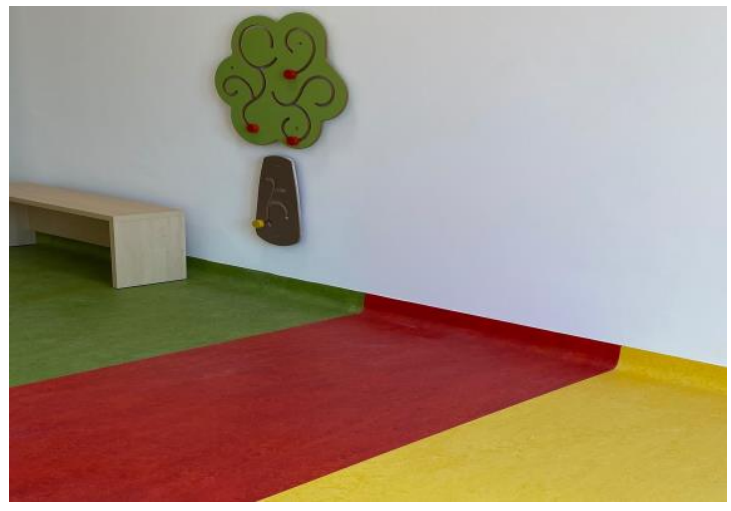

Fig. 2. Offers - the representation of the floor as a play surface. Source: author

Ryc. 2. Oferty - rysunek posadzki, pola do gier. Żródło: autor

Offers take into account motor development of a child and they might encourage to perform specifically defined tasks but on the other hand they are likely to be not visible if one is unable to use them (e.g. a disabled person and stairs). Not only do children observe offers but they want to touch them as well, as they are attracted by them (Wygotski 2002 p.92). From the point of view of architecture the offers described above might be limited to spatial elements with permanent and definable geometric structures but they are also likely to include cubatures with changeable plasticity and temporary deformations.

Offers include both plastic spacial elements with changeable geometry as well as modern technologies related to nanoparticles and simulators and at the same time they cover basic actions and reactions such as: sound, toys, science gardens and spaces where one is able to perform activities that release energy or creativity. It is believed that offers are constantly ready to fulfill their purpose. If their attractiveness changes, as a result of introducing new usage patterns, they suddenly become more visible to children and invite them to explore. Thanks to repetitive processes that take place - an area of development is created and it is a basic unit that enables children to receive proper education. A child becomes the central part of the area with occurring functions. Space that appears is a place of constructive activity of the subject. Offers are an opportunity to take action (Hornowska, et al. 2014, p.87). One of the most interesting examples of offer components, that is - 
permanent offers, might be floor or wall coverings that make it possible to generate extra light thanks to different technological solutions. This applies in particular to the drawings of floors in widely available communication areas and multi-functional rooms. Various floor or wall patterns can prove useful both in group and individual activities. One of such solutions could be luminance, i.e. the effect of light in the dark, the emission of light from a specific area of a material. Human eyes are most sensitive to green light, which seems bright, that is why "the glow" is green in the dark. ${ }^{1}$ This solution could be used when marking emergency exits and escape routes but also as a part of offers that are connected with entertainment for children (mazes, playgrounds, flat surfaces where children can play). Because the duration and the intensity of incandescence depends on the kind of light (and its duration and intensity as well) the surface was exposed to - the quality of incandescence is classified according to the level of brightness achieved in standard conditions as described in the DIN 67510-1 2009-11 document (Deutsches Institut für Normung/ German Institute for Standardisation). This means that in standard usage conditions, after two minutes in the dark, the element achieves brightness at the level of at least $108 \mathrm{mcd} / \mathrm{m} 2$. Luminance is the strongest in the first two minutes until the effect completely disappears after ten hours. Another solution in which materials with the effect of luminance might be used effectively are mechanisms detecting a physical presence of a person, what could be helpful in monitoring and coordinating various functions and didactic processes but also in providing users with safety (e.g. when entering an area that poses a threat to health, so called "dangerous areas") $)^{2}$, at the same time offers can support the creative processes, children's own artistic creation, especially if the activities involve a larger group of people, e.g. while organizing events, performances.

\section{NANOPARTICLES}

In recent years we have been observing a rapid growth of technologies based on ecological processes that let the used materials be recycled according to the principles of circular economy and those that minimize the usage of materials not only harmful to humans but also to the environment, both during the process of building and next - disposal. One of many directions of research are materials expanding the usage time of elements by changing their structure thanks to additional components. Solutions connected with nanotechnology that involves nanomaterials appeared with the development of technological thought. They led to more precision and new possibilities in the usage of construction materials. Durability, plasticity of chosen materials can be modified and it is also possible to introduce structures that protect from ageing and degradation of elements on a larger scale than before. The main purpose of projects based on materials using nanoparticles is to support specific goals and functionality - especially in the construction business. The most popular solution is changing the parameters of the strength of materials for cement and concrete. By changing the size of the cement grains - the binder hardens much faster, the particles split up evenly and the nanoparticles fill the pores and improve durability (Kaleta et al.2012 p.26). Besides construction elements - nanotechnology is also used in finishing materials such as: facade cladding, internal and external plasters, glazing, etc. Their main purpose is to slow the proces of ageing in the object but also to make it easier to keep it clean. It is possible to use materials more than once since they are made out of recyclables and components which are not harmful to the environment and which are biodegradable after fulfilling their purpose in construction. There are many examples of using nanomaterials in nursery buildings - mostly in finishing works concerning surfaces exposed to dirt or mechanical damage, e.g. external paint. Shortly after applying it to the wall, nanoparticles with special properties migrate to the surface of the area covered with paint. As a result - after the paint is dry the external part of the layer is extraordinarily hard but the internal one remains permanently flexible which makes the process of attaching to the surface (e.g. the wall) better and more permanent. The wall, being a surface in this particular technology is very hard

\footnotetext{
${ }^{1}$ The process of emiting light is based on the effect called phosphorescence, i.e. a kind of photoluminescence - some substances shine with their own light after they are previously exposed to light. In the process of production the surface of an object is covered with special paint that later, depending on the kind of the pigment, will emit light. After the end of the production process it is only necessary to expose such surface to the visible spectrum or artificial lightning to receive the effect of light emission.

${ }^{2}$ Materials of the Forbo company concerning new technologies in construction materials.
} 
because of the high smoothness of its structure and is characterized by high durability because any kind of dirt is unlikely to adhere to it, dust and other impurities can be washed off by rain (in case of paints used outdoors) or by ourselves - using water. The Nanotech system paint has little sensitivity to weather conditions, does not block free vapor diffusion, i.e. the "breathing" of the wall. The system consists of elastic foundation and very resistant paint. The undercoat is highly vaporpermeable but also does not allow for permeability of $\mathrm{CO} 2$ - a factor that might lead to corrosion of the surface and and the structure of the building. The paint, fusing into the surface, neutralizes stress appearing as a result of the influence of the weather conditions. Nanoparticles of such undercoat fuse into microcracks of the wall, making the whole surface air-tight, resistant to water; the surface of the undercoat keeps the level of elasticity that other paints cannot guarantee - and, most importantly - the process does not depend on the weather conditions. The paint can be used on both new and already existing elevations of buildings. It is characterized by high resistance to impurities thanks to the presence of nanoparticles and it is perfect for painting objects that are exposed to dust and particulates. The paint also masks all the cracks and scratches on the painted surface. Thanks to such paints we are provided with clean elevations for a very long time ${ }^{3}$. The elements descrived above, in which nanoparticles are used, are widely adopted in educational buildings. The main reason for their use concerns aspects related to easy cleaning and extended durability of the material. An equally important element is their resistance to long-term destructive processes - both external (natural environment) and internal (user actions), especially in educational facilities, where each element is explored by children. Therefore, nanoparticles have been widely used in both internal and external floor, wall, ceiling and wallpaper finishings. Thanks to nanotechnology it is possible to create coverings with increased antibacterial and UV radiation resistance. There are coverings (fig.3) with self-cleaning properties (external coverings or glass partitions), resistant to scratches and improving fire protection (e.g. wood impregnantion products). Structural elements allow the use of larger spans and an increase in acceptable loads. Unfortunately, nowadays it is not possible to determine if nanoparticles have any effect on people or they remain neutral.

Fig. 3. Glass arrangements with self-cleaning coverings. Source: author Ryc. 3. Zestawy szklenia z powłokami samoczyszczącymi Źródło: autor

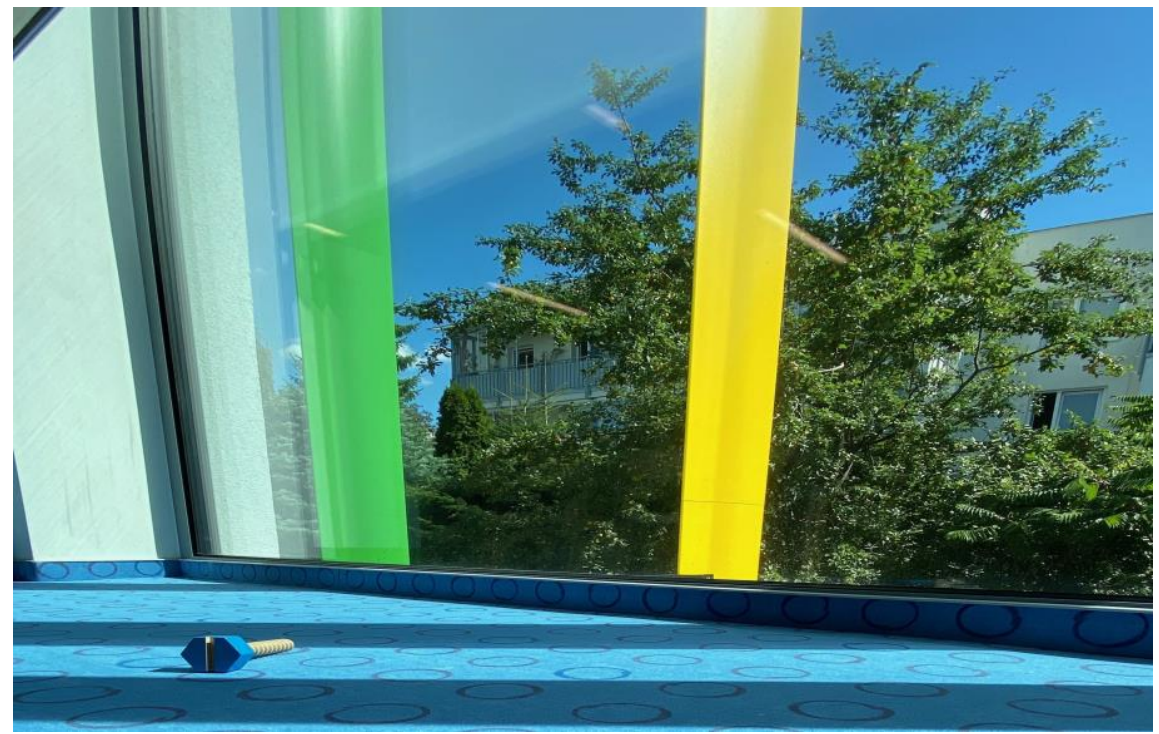

The research on the long-term influence of nanoparticles on living organisms is still being developed and with the current state of technological knowledge it is extremely hard to clearly determine if they influence it in a positive or a negative way. Especially if it comes to the level of

${ }^{3}$ Materials and technologies of Dekoral. 
concentration of particular chemical structures. Scientists claim that there is a connection between the lenght of exposure, the level of biological organization of the substance, concentration of nanoparticles and life expectancy of a generation of a particular organism (Kłosowicz 2020 p.16). There are no clear and objective patterns of checking the mechanisms and processes taking place in human body and the natural environment. That is why it seems reasonable to avoid applying technological solutions based on nanotechnology until unambiguous results of research (verifying assumptions made on the negative influence on a child's organism) are delivered. In particular, it applies to elements concerning food and including various kinds of food containers, dishes or silverware. Despite having numerous advantages - nanomaterials ought to be considered risky and used with moderation since our knowledge about them is still incomplete (Jasiński 2018, p. 553).

\section{PLASTICITY}

Mutual relations between spacial elements have shaped our perception of the construction and technological possibilities. Meanwhile, the crucial elements in partitions with adaptational parameters are plasticity and preserving the expected durability at the same time. The main problem concerns keeping the parameters and technical properties after exposing the objects to different processes. Therefore, it is necessary to pursue cyclical repetitiveness in plasticity and durability (Szymczak et al. 2006 p.3). Plastic deformation that might occur generates the existence of a structure with a specific texture and shape. The way the deformation proceeds is associated with original parameters that the material comes back to after fulfilling a specific task. That is why a negative possibility of weakening the material as a result of repetitive deformations is such an important factor. The research on materials and their changeable plasticity shows that the program of cyclic loads (the pendulum cycle) caused the weakening of the material, which was expressed in the reduction of the plasticity of the surface. It is also interesting that the deformation caused by uniaxial monotonic stretching of the same value as in the cyclic program led to the weakening by over $11 \%$ in relation to the material after the cyclic loading (Szymczak et al. 2006, p. 7). Other examples of plasticity are SMA materials - metal alloys that can change shape as a result of temperature or force. The materials change their shape and come back to the original one (Stopy z pamięcią kszt$a t t u)$. An element with assumed geometry transforms from its spatial form to the programmed shape. As a result of a deliberate action, it returns to the initial phase or to the planned deformation stage. The shape memory allows not only a one-way memory effect, but also a two-way one, which is characterized by the transition from the original shape to the shape given as a reversible process. The main element of the initiation is the change of temperature, which currently limits the development possibilities in terms of adapting to architectural needs. At the same time, in addition to the thermal method discussed, the change of the shape is also possible through a magnetic field or also through loading. Possibilities of a wider use of materials with shape memory open new fields for generating temporal spatial frames for cubature objects - internal structures in particular. The material that stimulates the imagination for possible spaces of the future because of its properties and possibilities that appear thanks to them is Ni-Ti alloy. The composition of $\mathrm{Ni}$ - $\mathrm{Ti}$ alloys can vary from $48 \%$ to $52 \%$ and has a large impact on the temperature of the transformation of the hightemperature phase into martensite (this temperature may vary from -40 to 100 degrees Celsius). These alloys have the best properties among SMA - in a crystalite it is possible to achieve a reversible deformation of $8 \%$ and stress on return to its previous shape up to $800 \mathrm{MPa}$ (Stopy z pamięcią kształtu).

The described materials and processes do not apply to material and design solutions directly related to the current construction technology and the facilities implemented today. However, they highlight new opportunities that designers and producers might have in the nearest future. Solutions that are almost achieveable at present. Nurseries are objects where applying the materials and technological solutions described above is possible. Especially if it comes to the functions connected with education, such as: rhythmics, music, but also - a child's motor development through play and movement. By using plasticity in our offers, we expand the boundaries of attractiveness for users, engaging structures that cooperate with specific utility models. Deformations and plastic 
deformations that take place as well as the possibility of using materials with shape memory allow for adopting design solutions based on division: a skeleton and soft tissues. The division into two coexisting elements makes it possible to provide a constant external spatial separation with a plastic and deformable set of soft tissues that are directly affected by the generated functional patterns. In order to achieve the described goals, construction technology and the design process should evolve and start to apply on a larger scale the systems used in the design of e.g. mechani$\mathrm{cal}$ and automatic structures, the principle of which is based on a durable load-bearing skeleton with multi-directional space and internal complementary elements. The proper load-bearing structure, suitably rigid and non-deformable, surrounds the utility areas with variable spatial parameters. The option presented above is an optimal scheme, which, unfortunately, due to the advancement of current research, and the acceptable costs of the construction of facilities, is unattainable. However, it does not mean that it will not become a standard in the design of educational facilities in the near future. The issue of plasticity in a nursery building, which is being discussed, will be concentrated mainly on one part of the space. It will be based on two main aspects. The first one is multifunctionality characterized by the lack of need to provide the part of the building with permanent, independent elements of equipment that would refer to particular functions (dance, rhythmics, reading, image projection). Elements of the spacial structure will be able to perform various functions depending on the ongoing expectations. The second aspect is flexibility which will be a change resulting from current needs connected with education and will make it possible for children to perform the process of creation as a part of targeted activities. This flexibility will provide a wide spectrum of interactions from moveable spacial structures, moving to the rhythm of music, through smooth and acoustic partitions when the need for silence and rest is expected, to the projection of spacial images and shapes in case of experimental activities.

\section{AMBIENT MIRRORS - SIMULATORS}

Simulators demonstrate phenomena occurring in the environment as a result of the emerging functions or deliberate actions of the participants of the research process. By using multi-path solutions it was possible to enrich the cognitive impulses necessary for the development of children's interests and their physical development. Modern simulators should not isolate children from their real environment and minimize the process of socialization. The main priority is to raise interest and generate the need for cooperation between children, both in purposeful work and free play. Currently, we can use technical solutions that are not limited to an individual user service but can involve a group of participants in the simulation. These are devices working in a distributed system scheme based on image and surround sound projection. In order to strengthen the transmission and the reception - apart from using devices with very high conversion power - it is necessary to have avant-garde software that goes beyond the typical operating pattern. Not only does the software provide cyclical simulations but it also adapts to new functions that do not always repeat in the same templates. This creates a combination of computing power and program functions. An important parameter in the software is the preceding simulation factor, the erroneous assumptions of which may counteract the operational guidelines and expectations of people participating in the function. Thus, the cognitive process is much deeper and more efficient because - apart from the purposeful simulation - the mutual interaction of participants in response to the stimuli arises. The resulting interactions can be either purposeful or spontaneous. Currently, it is not inadvisable to use simulators in educational facilities based on the adaptation and development of simulation technologies used in a wide spectrum, e.g. cognitive perception of the environment and moving around by simulating a real hike (e.g. through the forest at different times of the year). Demonstration can be realized through the image via a high-resolution laser projector and an FSR spherical mirror. A spherical display is used to ensure the effect of the surroundings and the sense of being in a virtual space. It is supplemented by a sound system and equipment elements, such as: floors (imitating the features of outdoor surfaces like grass, sidewalks), armchairs, etc. Another solution is to rely on a spherical display and a globe made of GRP composites. The multi-channel projection is carried out in the visible spectrum and in NVG and is realized with the use of the professional installation projectors designed for $7 / 24$ simulations. The solution is complemented by HR hemispherical optics. In the further search for optimal solutions through the use of 3D autostereoscopic moni- 
tors in Ultra-D MultiView technology, which allow viewing 3D images directly, we can eliminate the need to use 3D glasses, which is very important if we take into account older children attending nurseries. The ultra-D technology generates light that absorbs human perception of depth in a way similar to the real, three-dimensional world. The Ultra-D optical solution is based on two fundamental depth cues - "stereopsis" and partial motion parallax. It gives a more natural 3D experience. In Ultra-D we no longer have to look for the "best" viewing angles of a 3D image, as is the case with the lenticular technology or a parallax barrier. We can see them from any position - without limits ${ }^{4}$. The development of the technology based on flexibility of use is an interesting direction of research.

Simulator-related solutions can be widely used in educational facilities functioning as nurseries. At present, the scope of their application is on one hand limited because of financial aspects, and, on the other - parents' and caregivers' lack of trust concerning new technologies. That is why interactive teaching aids in the form of a "magic carpet" are most often used in nursery building rooms for dedicated physical exercises and games. A "magic carpet”, to a limited extent, through various games, enables the improvement of motor skills and eye-hand coordination (fig.4). Simultaneously, simulators described above have two main drawbacks. The first disadvantage is the necessity to provide fixed spatial elements with specific parameters and locations. The previously mentioned elements can only perform specific functions within the parameters with the given limit values. Thus, their adaptability to fulfill various needs of different functions is severely limited. The second disadvantage is related to the limitation or even the deprivation of the physical contact with nature and the surroundings. At the same time, the simulators activate curiosity of their users but in complete detachment from reality. Children's "life" experiences arise in sterile conditions without them being aware of the side effects of the explorations.

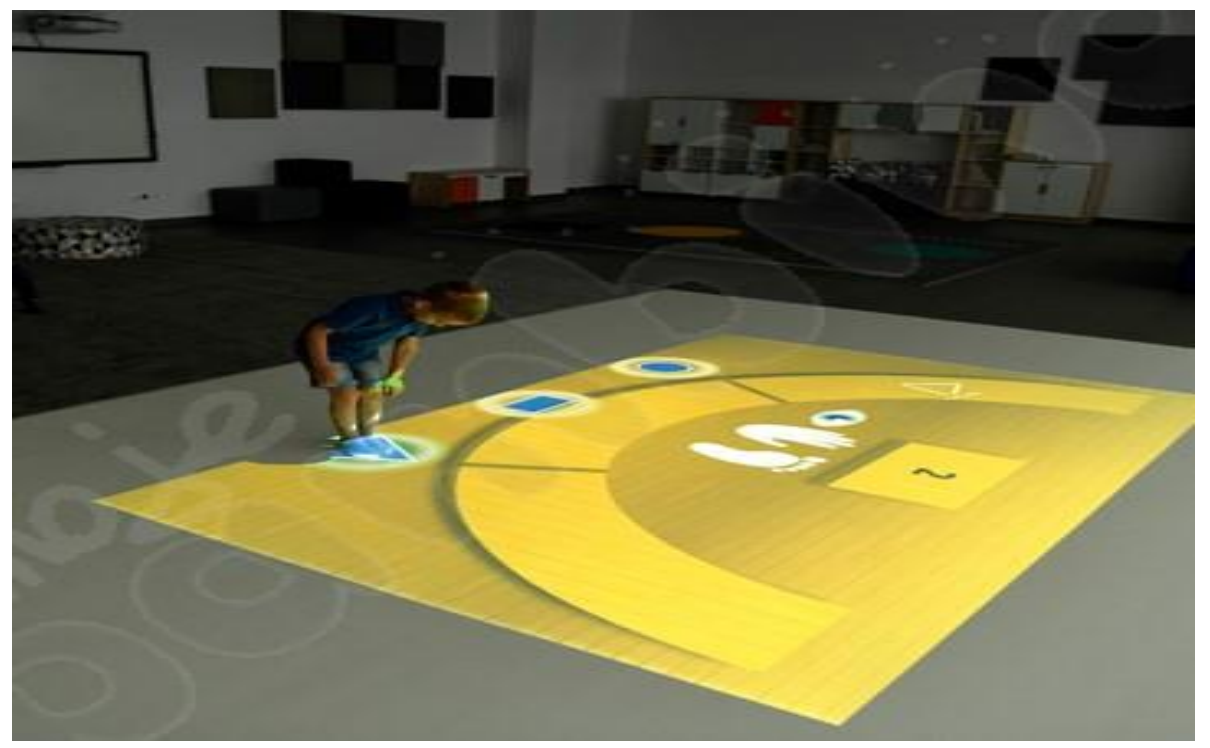

Fig. 4. A magic carpet Source: mojebambino Ryc. 4. Magiczny dywan Źródło: mojebambino

\section{SOUND}

Safety in a nursery is not limited only to reducing the stress of separation between a child and a parent or a guardian. It should also be reflected in the proper organization of space, the selection of toys but also in the reduction of unnecessary or negative stimuli. Therefore, dedicated methods of work with children are required, increasing their activity and the possibility of independent play and interaction with their peers. Due to the limited independence of children in nurseries, the partic-

\footnotetext{
${ }^{4}$ Based on materials and products of Delta sp. j. Krentkowski, Hus, Białystok.
} 
ipation of caregivers showing high empathy, sensitivity and patience is also necessary. The interaction between the need for independence and the consistent and empathetic support creates an atmosphere in which activity and motivation to act are the natural needs for children. Practical skills increase, and together with their development, the spectrum of interest and research needs becomes bigger. One of the elements of research is music and sounds of different intensity. The main element of toddler and post-toddler age is a lullaby. A lullaby is a crucial element of early childhood, a piece of music characterized by slow pace, used to soothe and calm an agitated child. (Sadowska 2016 p.247). While listening to a lullaby thanks to the rhythmical repetition of musical elements - certain structures are acquired and the additional gentle rocking movements connect the experience of the rhythm with the movement of the body. But a lullaby is not the only musical element that allows a child to explore and thus acquire new experiences. Sounds combined with the possibility of getting to know and discovering new objects and spaces expand the knowledge about the surroundings. It is also a development of motor skills from rhythmic clapping, stomping, through improvisations in the use of various toys or simple musical instruments (a rattle, a drum). In order to provide children with musical education, attention should be paid to planning the space surrounding them (Sadowska 2016 p.249). The created space is divided into zones with different tasks and functions, while maintaining full variability adapted to the current needs or challenges. There are no inanimate structures in such space - structures that only create functional "decorations". One of the new dimensions is sound and the way it reflects from a material with variable plasticity. Sounds appearing in space are soft and extremely pleasant for the listeners. The components combined with a low volume of sound are the most important part of the musical activation. They help to satisfy the need of personal expression. The sound cooperating with the movement additionally strengthens the cognitive abilities of the objects, the spatial structures (textures) and the functions occurring in the surroundings. Child development is integrated with the song, physical activity to music, repetitive activities in a rhythm inspired by sound. Not only is music educational but it also covers the so-called everyday activity of a child, stimulating his or her development and deepening socialization with other children during joint activities.

\section{CONCLUSIONS}

In search of an ideal space, let us imagine a lecture space separated by structures. At first it is implied that space is a permanent element with typical characteristic points such as: openings, floors and ceilings. We are in a well-known and "tame" "box". Meanwhile, it is a dynamic structure frozen in anticipation of operational guidelines and the results of the functions that will arise and take place in space. The variability of the spatial structure can develop in many directions:

- changes in internal cubature

- changes in material structure

- changes in the atmosphere of the room

The change of internal cubature consists in adapting to the expected results as a result of the given functions. The change prepares for new events that are planned for a specific time frame. Due to the functional assumptions, the structure has parameters of plastic variability that guarantees a return to the original initial parameters and to new guidelines. The change in the material structure is adjusted to the current educational and cognitive needs. The material adopts a structure with extremely different parameters - from elements integrated with music, moving to the rhythm of sounds, through surfaces ranging from the rugged to the perforated ones. The plasticity of the material also allows for various activities for which acoustic parameters or hygienic sterility currently require specialized finishing. Suddenly, in one shared space, it is possible to organize movie screenings, musical events combined with dance, but also artistic activities related to the free creation of space (e.g. murals). The combination of two aspects related to plastic change releases unlimited creative potential not only in terms of the possibility of the design creation, but mainly in terms of meeting the utility needs. It is also an additional background for the changes related to the fleeting atmosphere of the moment. This is an opportunity for users to get a subjective feeling of being in task areas. It is influenced not only by variable spatial and material parameters, but also by the created physical conditions stimulating the senses, e.g. smell, touch. In a word - direct physical 
interactions in the cognitive function. New design, the technological and material possibilities support and reflect the expected activities of children in nurseries. Variable structures along with offers contribute to the development of children's perception of their environment. They help to obtain new information by children, but also are a source of objective data on children's behavior necessary for the constant adaptation of the care and the educational program. There are patterns that stimulate play, movement, speech, touch and self-realization through an adaptive childoriented space (joyful and serious children), dynamic arrangements created in cooperation with children and in response to their expectations, offers of various nature using stimulators, areas of adaptation to the temporal needs and challenges, controlled changes of the context and planned interactions, dynamic expression zones with mobile equipment. A living workshop is co-created with multi-format elements essential for the proper development of the user. At the same time, it is a challenge that brings design to a new level. In order to meet the above described issues, it is necessary to change the design system completely, move from static objects to dynamic forms and offers, provide opportunities for development in a safe environment, the priority of which is included in educational programs. The design scheme should take into account not only the design solutions available today, but also provide the possibility of introducing, in the near future, spatial elements related to the plasticity of the material. That is why the structure of the object ought to be flexible and mobile enough to provide variability in response to new expectations and challenges. Thus, a scheme is established - based on a rigid, cellular skeleton around which soft tissues with variable functional and spatial parameters are created. Tissues independent of the skeleton can be replaced with more technologically advanced ones. That is why the main task of a designer should be not only to synthesize the binding construction law and technical possibilities, but also to search for universal spatial patterns. The schemes are a space for functional designs supported by modern materials and technologies in response to possible utility challenges for nursery buildings. Therefore, it is important that each design solution is preceded by an analysis of the anticipated events taking place in a given spatial structure, supported both by technology and an educational program. In order to meet such expectations, multi-dimensional consultations with both an Investor and the teaching staff, who will be one of the main components of the nursery, are necessary. It is important to pay attention to the fact that not all currently available technologies are $100 \%$ safe for the user or that their cost is adequate to the offer and the possibility of rational use. This applies in particular to both nanotechnology and complex simulators. The solutions described above are so important because in rural areas there is practically no access to childcare facilities for young children, which may constitute a barrier in reducing the differences in the level of education between rural and urban areas (Piętka-Kosińska et al. 2010 p44). Increasing the attractiveness of the place, supported by educational programs, may affect the new perception of nursery buildings.

\section{BUDYNEK ŻŁOBKA, JAKO TŁO O ZMIENNYM WYPEŁNIENIU W ADAPTACJI DO AKTUALNYCH POTRZEB. JEDNOSTKI IMPORTUJĄCE I ODDZIAŁYWUJĄCE NA SIEBIE}

\section{WPROWADZENIE}

Budynek żłobka może to być miejsce o całkowicie niekonwencjonalnych rozwiązaniach technologicznych i projektowych mających bezpośredni wpływ na możliwości rozwojowe dziecka. Miejsce gdzie procesy rozwoju i symulacji percepcji wspomagane są zaawansowaną technologia. Nieinwazyjne rozwiązania techniczne, będące w ciągłej gotowości na nowe funkcje dostosowane do rzeczywistych, indywidualnych, potrzeb dzieci i ich własnej drogi eksploracji otaczającego środowiska. Elementy, które wspomagają naturalną ciekawości i nie zaburzają swobodnej zabawy poznawczej. W żłobku następuje nie tylko socjalizacja, zrównoważona symulacja rozwoju osobistego ale także 
realizowanie są projekty wsparcia dla rodziców. Żłobek zmienia się w otwarta pracownię zarówno dla dzieci jak i rodziców. W poszukiwaniu odpowiedzi na pytanie jak placówka może stać się miejscem nawiązującym w swej organizacji do rodziny małego dziecka, należy odwołać się do stanowiska teoretycznego, które podkreśla, że dorosły podejmuje starania budowania zrównoważonych relacji z dzieckiem. (Telka 2009 s. 47). Dorosły jest cały czas obok, gotowy do działań wspomagających gdy dziecko ma trudności z realizacją określonego zadania lub dezaprobujących w przypadkach negatywnych zachowań. Działania dorosłego tworzą tzw. dobrą sprzyjającą atmosferę. (Telka 2009 s.45). Powstałe wzajemne relacje budują przestrzeń, której składnikami są wzory funkcjonalne (zabawa, edukacja), powtarzalne czynności - (posiłek, higiena osobista) oraz obecność dorosłych (opiekunowie, rodzice). To struktura, która z jednej strony charakteryzuje się cyklicznością i rytmiką tych samych działań a równocześnie to bardzo dynamiczna przestrzeń o ciągłych i zmiennych procesach zachodzących nieustająco. Równocześnie wytwarza i określa bezpieczne granice twórczości, ciekawości i autonomiczności. Powtarzalność generuje porządek i świadomą relację z istniejącym otoczeniem. Dynamika spontaniczności to pole nieskrępowanej bezpiecznej eksploracji środowiska, a autonomiczne decyzje ukierunkowane na określone cele. Spoiwem łączącym poszczególne elementy są komunikaty, funkcje i działania kreowane przez uczestników a także powstałe formy w wyniku zachodzących reakcji pomiędzy uczestnikami.

\section{PRZESTRZEŃ}

Przestrzeń w obiekcie tworzą przegrody pionowe i poziome wydzielające ją z szerszego kontekstu środowiskowego. Wydzielenie oparte jest doświadczeniem nabytym przez ludzkość i powiązana z rozwojem technologii budowlanej. Przegrody moga być uznane, jako jeden ze składników podstawowej potrzeby w zakresie bezpieczeństwa wg. teorii A. Masłowa (Hierarchia potrzeb 1943). Dzięki wydzieleniu można ukryć się przed niebezpieczeństwem zewnętrznym, być niezależnym od zmiennych warunków pogodowych. Wydzielona przestrzeń buduje poczucie bezpieczeństwa i przetrwania. Z czasem wydzielenia przestrzeni stały się także jednostkami generującymi określone funkcje i procesy życiowe ale wciąż mocno zintegrowane $z$ otaczającym człowieka środowiskiem. Jednakże z biegiem lat człowiek poprzez ciągły rozwój i nieustającą potrzebą zapewnienia coraz lepszego i wygodniejszego komfortu życia usunął lub zminimalizował liczne połączenia ze środowiskiem zewnętrznym, a w tym z otaczającą przyrodą. Spełnienie coraz nowych potrzeb i oczekiwań stało się siłą napędową dla dynamicznego rozwój technologii oraz zmiany postrzegania jednostki ludzkiej w otoczeniu środowiska. Punktem zwrotnym w spojrzeniu na rozwój ludzkości i jej wpływ na otoczenie stały się dopiero potężne zmiany klimatyczne spowodowane intensywnym rozwojem przemysłu, rolnictwa, niekontrolowanej urbanizacji i masową turystyką. (Myga-Piątek $i$ in. 2009 s.37). Powstałe zagadnienie skierowały prace naukowe na nowe tory mające na celu doskonalenie obecnych rozwiązań przemysłowych uwzględniających ochronę środowiska ale także minimalizujących wpływ działań człowieka na otoczenie wprowadzając substytuty fizycznych obecności w określonych lokalizacjach.

\section{OFERTY}

Postrzeganie przegród przez użytkownika wraz z ich wykorzystaniem w celu realizacji określonych zadań i zaspokajania zmiennych potrzeb wprowadza nowe elementy o niekonwencjonalnych składowych. Badania przeprowadzone w 2011-2012 na terenie Polski w ramach projektu badawczego pt.: Adaptacja narzędzi do diagnozy jakości otoczenia fizycznego i społecznego dzieci w wieku od 6 do 36 miesiąca życia. (Hornowska i in. 2014 s.111-132) ujawniają dodatkowe aspekty roli środowiska w trakcie rozwoju dziecka. Główne wyniki badań uzmysławiają, iż wraz z rozwojem dziecka następują zmiany w potrzebie dostępności lub bliskości opiekunów. Zwiększająca się wraz z wiekiem naturalna potrzeba samodzielnej eksploracji otoczenia odgrywa bowiem niezwykle ważna role w rozwoju dziecka, mając wpływ na kształtowanie się jego właściwości fizycznych, poznawczych oraz osobowych. (Hornowska i in. 2014 s.134). Badania dotyczyły między innymi związku pomiędzy zróżnicowanym otoczeniem dziecka a poziomem jego rozwoju ale także precyzowały jakie elementy składowe fizycznego otoczenia są istotne dla rozwoju w okresie wczesnego dzieciństwa. 
Poruszane aspekty są jednymi z wielu kluczowych badań dotyczących zagadnień związanych z odkrywania otoczenia i środowiska przez dzieci, dla których sam proces eksploracji staje się osią aktywności. Ciągła eksploracja a także nieustające eksperymentowanie z przedmiotami wpisane jest w rozwój dziecka. Zgodnie z teorią Gibsona, wiedza dziecka o otoczeniu oparta jest na wynikach samodzielnej eksploracji. (Gibson 1988 s.7). Równocześnie procesy poznawcze analizowane są jako relacje pomiędzy elementem działającym a rzeczywistym otoczeniem, w którym element przebywa. Rozwinięciem myśli są „oferty”, czyli procesy wielotorowe lub elementy strukturalne posiadające możliwość wpływania na rozwój dziecka. Jako oferty możemy traktować nie tylko zabawki ale także elementy przestrzenne i kubaturowe z którymi ma do czynienia użytkownik żłobka np. schody, drzwi itp. (ryc.1, 2). Uwzględniają rozwój motoryczny oferty mogą zachęcać do wyznaczonych kierunkowych działań ale równocześnie mogą być niewidoczne w przypadku braku możliwości skorzystania z nich (osoba niepełnosprawna a schody prowadzące na piętro). Oferty kuszą dziecko, które nie tylko je obserwuje ale także chce je dotknąć. Chce dotknąć wszystko co widzi i słyszy. (Wygotski 2002 s.92). Z punktu architektonicznego opisywane oferty mogą nie tylko ograniczać się do elementów przestrzennych o stałych i wyznaczalnych strukturach geometrycznych ale także mogą obejmować kubatury o zmiennej plastyczności i czasowych deformacjach. Oferty obejmują zarówno plastyczne elementy przestrzenne o zmiennej geometrii jak i nowoczesne technologie związane z nanocząstkami i symulatorami a równocześnie obejmują podstawowe działania i reakcje jak: dźwięk, zabawki, ogródki doświadczalne, przestrzenie upustu energii lub kreacji. Przyjmuje się, że oferty są w ciągłej gotowości do działania. Zmiana ich atrakcyjności, w wyniku wprowadzonych wzorów użytkowych, powoduje, iż stają się nagle widoczne dla dzieci i są zaproszeniem do nowych odkryć. W trakcie zmiennych lub cyklicznych procesów powstaje strefa najbliższego rozwoju, która jest bazą i zaczynem prawidłowego działania edukacyjnego. Strefa ukierunkowana zostaje na dziecko czyniąc go najważniejszą składową zachodzących funkcji. Powstała przestrzeń jest obszarem konstruktywnej aktywności podmiotu. Oferty to możliwość działania. (Hornowska i in. 2014 s.87). Jednym z wielu interesujących przykładów składowych ofert tzw. oferty stałe mogą być wykończenia posadzek lub ścian oparte na wykładzinach, które dodatkowo mogą, poprzez zastosowane rozwiązania technologiczne, generować oświetlenie. W szczególności dotyczy to rysunku posadzek w ciągach komunikacji ogólnodostępnej oraz w salach wielofunkcyjnych. Różnorakie wzory posadzek lub ścian mogą służyć do zabawa grupowych jak i indywidualnych. Jednym z możliwych rozwiązań jest efekt blasku w ciemności tzw. luminancja: emisja światła z określonego obszaru materiału. Ludzkie oko jest najbardziej wrażliwe na zielone światło, które wydaje się jaśniejsze, dlatego w ciemności „Glow” świeci na zielono ${ }^{5}$. Rozwiązanie może być używane jako trwały środek do wskazywania wyjść ewakuacyjnych i oznaczania dróg ewakuacyjnych ale także jako cześć ofert do zabawy dzieci (pola gier, labirynty). Ponieważ czas trwania i moc żarzenia zależy od czasu i natężenia źródła światła, na które było narażone wykończenie, jakość żarzenia jest klasyfikowana według poziomu jasności i czasu trwania osiągniętego $\mathrm{w}$ warunkach standardowych zgodnie z normą DIN 67510-1 2009-11: pomiary potwierdzić klasyfikację „klasa A” . Oznacza to, iż w normalnych warunkach użytkowych po 2 minutach w ciemności element osiąga jasność co najmniej $108 \mathrm{mcd} / \mathrm{m} 2$. Iluminacja najsilniejsza jest w pierwszych minutach, aż do całkowitego zaniku po 10 godzinach. Kolejnym elementem związanym z tego typu materiałem są poszukiwania dla rozwiązań odczytujących obecność osoby, co nie tylko może pomóc w monitoringu i koordynacji planowanych funkcji z procesami dydaktycznymi ale także bezpieczeństwie użytkowników (wtargnięcie w obszary o podwyższonym ryzyku utraty zdrowia tzw. niebezpieczne obszary) ${ }^{6}$ a równocześnie wspomagać procesy twórcze, własną kreację plastyczną dzieci, w szczególności gdy działania obejmują większa grupę osób np. podczas wspólnych prac związanych z uroczystościami (przedstawienia).

\footnotetext{
${ }^{5}$ Działanie a właściwie świecenie opiera się na zjawisku fosforescencji, czyli rodzaju fotoluminescencji - świecenia pewnych substancji światłem własnym wywołanym wcześniejszym jej naświetleniem. W procesie produkcji pokrywa się powierzchnię specjalną farbą, która w zależności od typu barwnika będzie później emitować światło. Następnie po zakończeniu procesu produkcji wystarczy taki materiał naświetlić światłem widzialnym lub sztucznym w celu uzyskania efektu świecenia.

${ }^{6}$ Materiały informacyjne firny Forbo dotyczące nowych technologii w materiałach budowlanych.
} 


\section{NANOCZĄSTKI}

W ostatnich latach następuje rozwój technologii opartych na procesach ekologicznych pozwalających na wielokrotny odzysk użytych materiałów zgodnych z zasadami gospodarki obiegu zamkniętego, a także minimalizujących użycie materiałów szkodliwych nie tylko dla człowieka ale także dla środowiska, zarówno w procesie budowy jak i późniejszego ich unieszkodliwiania. Jednym z wielu kierunku poszukiwań są materiały wydłużające czas użytkowania elementów poprzez zmianę ich struktury za pomocą dodatkowych komponentów. W trakcie rozwoju myśli technicznej pojawiły się rozwiązania związane z nanotechnolgią, która zajmuje się naonomateriałami. Powstałe rozwiązania technologiczne otworzyły nowe możliwości wykorzystywania materiałów budowlanych i bardziej precyzyjne działanie w oczekiwanych założeniach. Możemy wpływać na wytrzymałość, plastyczność wybranego materiału, wprowadzać struktury zabezpieczające przed powstawianiem zjawisk starzenia się i degradacji wykonanych elementów w dużo większym zakresie niż dotychczas. Główne zadanie rozwiązań projektowych opartych na materiałach wykorzystujących nanocząstki to wsparcie przy w określonych celach projektowych i funkcjonalnych. Szczególnie bardzo popularne i szeroko stosowane są rozwiązania w budownictwie. Najbardziej popularnym rozwiązaniem jest zmiana parametrów wytrzymałościowych dla cementu i betonu. Poprzez zmniejszenie wielkości ziaren cementu spoiwo twardnieje o wiele szybciej, cząstki rozkładają się równomiernie a nanocząski wypełniają pory zwiększając wytrzymałość. (Kaleta, Kołodziej 2012 s.26). Poza elementami konstrukcyjnymi nanotechnologia jest stosowana także w elementach wykończeniowych takich jak: okładziny zewnętrzne, tynki zewnętrze i wewnętrzne, przeszklenia itp. Główne ich działanie skierowane jest nie tylko na zmniejszenie procesu starzenia się obiektu ale także na zapewnienie łatwości utrzymania go w czystości. Wytwarzane są materiały do ponownego wykorzystania z odzysku surowców wtórnych ale także z komponentów nieszkodliwych dla środowiska i ulegających biodegradacji po spełnieniu swoich wytycznych użytkowych w budownictwie. Jednym z wielu przykładów wykorzystania materiałów opartych na nanotechnologii w budynkach żłobkowych są prace wykończeniowe, w szczególności dotyczące powierzchni narażonych na zabrudzenia lub uszkodzenia mechaniczne. Przykładem może tu być produkt w postaci farby powierzchniowej. W farbie zaraz po nałożeniu jej na ścianę, nanocząsteczki o specjalnych własnościach migrują na powierzchnię powłoki malarskiej. Końcowy efekt, po wyschnięciu farby jest taki, że zewnętrzna część powłoki jest niezwykle twarda, natomiast wewnętrzna pozostaje trwale elastyczna, co sprzyja lepszemu i trwalszemu zespoleniu z podłożem. Powierzchnia ściany, czyli powłoki malarskiej w tej technologii, z powodu wyjątkowo wysokiej gładkości strukturalnej jest bardzo twarda, charakteryzuje się wysoką trwałością, gdyż wszelki brud o wiele gorzej do niej przywiera, kurz i inne zanieczyszczenia zmyje sam deszcz (w przypadku farb stosowanych na zewnątrz) bądź my sami wodą. Farba z systemu Nanotech poza tym, że jest farbą mało wrażliwą na czynniki atmosferyczne, nie blokuje swobodnej dyfuzji pary wodnej, czyli oddychania ścian. System składa się z podkładu elastycznego oraz farby o dużej odporności. Farba podkładowa jest o wysokiej paroprzepuszczalności, i zarazem o bardzo niewielkiej przepuszczalności CO2, czynnika, który może powodować korozję powłoki jak i struktury budowli. Wtapiając się w podłoże rozkłada naprężenia powstające w wyniku oddziaływania atmosferycznego. Nanocząsteczki tego podkładu wnikają w mikropęknięcia ścian, uszczelniając tym samym całą powłokę, uodparniając przed wpływem wody, powłoka podkładu utrzymuje nieosiągalną przy zwykłych farbach elastyczność, co znamienne, niezależnie od warunków atmosferycznych. Farbą możemy malować istniejące już jak i nowe elewacje budynków. Farba charakteryzuje się wysoką odpornością na zabrudzenia z uwagi na zawarte w niej nanocząsteczki, znakomicie nadaje się do malowania obiektów, które są narażone na zakurzenie i zapylenie. Farba dodatkowo maskuje wszelkie spękania i rysy na malowanej powierzchni. Dzięki farbom tego systemu gwarantujemy sobie czyste fasady przez długi okres czasu. ${ }^{7}$ Opisywane powyżej elementy w których wykorzystuje się nanocząstki szeroko stosowane są w budynkach edukacyjnych. Główną przyczyna stosowania ich dotyczy aspektów związanych z łatwym utrzymaniem czystości oraz wydłużoną żywotnością materiału. Równie istotnym elementem jest odporność na długofalowe procesy destrukcyjne zarówno zewnętrzne (środowisko naturalne) jak i wewnętrzne (działania użytkowników) w szczególności w obiektach edukacyjnych, gdzie każdy element poddanych jest eksploracji przez dzieci. Dlatego nanoczątki znalazły szerokie zastosowanie w wykoń-

\footnotetext{
${ }^{7}$ Materiały i technologie firmy Dekoral.
} 
czeniu posadzek, ścian, sufitów oraz okładzin ściennych zarówno wewnętrznych jak i zewnętrznych. Dzięki nanotechnologii możliwe jest wykonywania powłok o zwiększonej odporności antybakteryjnej, odporności na promieniowania UV. Pojawiły się powłoki (ryc.3) o parametrach samoczyszczących (zarówno dla okładzin zewnętrznych jak i przegród szklanych), odpornych na zarysowania i zwiększających parametry pożarowe (np. impregnaty do elementów drewnianych). Elementy konstrukcyjne pozwalają na stosowanie większych rozpiętości i zwiększenie dopuszczalnych obciążeń. Niestety na dzień dzisiejszy nie można jednoznacznie stwierdzić neutralności nanocząstek w stosunku do ludzi. Badania dotyczące długofalowego oddziaływania nanocząstek na organizm żywy ciągle są w rozwoju i w obecnym stanie wiedzy technicznej bardzo trudno jest jednoznacznie stwierdzić ich negatywny lub pozytywny wpływ. W szczególności dotyczy to wysokości stężenia danych struktur chemicznych. Naukowcy przewidują zależność pomiędzy czasem ekspozycji, poziomem organizacji materii, stężeniem nanocząstek a długością życia generacji danego organizmu. (Kłosowicz 2020 s.16). Brak jednoznacznych i obiektywnych szablonów, wzorów dla zbadania mechanizmów i procesów zachodzących w organizmie człowieka i środowiska naturalnego. Tym samym celowe wydaje się możliwe unikanie szerokiego stosowanie rozwiązań technologicznych opartych na nanocząstkach do czasu otrzymania jednoznacznych badań weryfikujących przyjęte założenia w zakresie negatywnego wpływy na organizm dziecka. W szczególności dotyczy to elementów związanych z wyżywieniem a obejmujących różnego rodzaju pojemniki, naczynia czy też sztuce. Pomimo wielu zalet nanomateriałów ale również dlatego, iż wiedza o nich jest nadal niepełna, powinno się je traktować jako obarczone ryzykiem i stosować z umiarem. (Jasiński 2018, s. 553).

\section{PLASTYCZNOŚĆ}

Wzajemne relacje pomiędzy elementami przestrzennymi ukształtowały nasze postrzeganie możliwości budowanych i technicznych. Tymczasem w przegrodach o adaptacyjnych parametrach istotnym elementem jest plastyczność przy zachowaniu oczekiwanej wytrzymałości. Główny problem dotyczy zachowania parametrów i zadanych właściwości technicznych po zmiennych stanach przetworzenia. Tym samym oznacza dążenie do powtarzalności cyklicznej w plastyczności i wytrzymałości. (Szymczak i in. 2006 s.3). Możliwa deformacja plastyczna generuje powstanie struktury o określonej teksturze i kształcie. Przebieg deformacji powiązany jest z parametrami wyjściowymi do których materiał wraca po spełnieniu określonego zadania. Dlatego tak ważnym i istotnym czynnikiem jest negatywna możliwość osłabienia materiału w wyniku powtarzających się odkształceń. Badania prowadzone nad materiałami i ich możliwościami zmian plastycznych pokazują, iż przeprowadzony program obciążeń cyklicznych [cykl wahadłowy] wywołał osłabienie materiału wyrażające się zmniejszeniem powierzchni plastyczności. Interesujący jest także fakt, że deformacji zadawana na drodze jednoosiowego monotonicznego rozciągania o wartości jednakowej jak przy programie cyklicznym wywołała osłabienie o przeszło $11 \%$ większe w stosunki do materiału po obciążeniu cyklicznym. (Szymczak i in. $2006 \mathrm{~s} .7$ ). Rozwinięciem plastyczności są materiały SMA, stopy metali, które mogą zmieniać kształt w skutek działania temperatury lub siły. Zmiana kształtu polega na powrocie materiału do kształtu wyjściowego (Stopy z pamięcią kształtu). Element o przyjętej geometrii zmienia swoja postać przestrzenną do zaprogramowanego kształtu. W wyniku działania celowego powraca ponownie do fazy wyjściowej lub do planowanego etapu odkształcenia. Możliwości pamięci kształtu umożliwiają nie tylko jednokierunkowy efekt pamięci ale także dwukierunkowy, który charakteryzuje się przejściem od kształtu pierwotnego do kształtu nadanego jako proces odwracalny. Główny elementem inicjacji jest zmiana temperatury co mocno ogranicza obecnie możliwości rozwoju w zakresie dostosowania do potrzeb architektonicznych. Równocześnie poza przedstawioną metodą termiczną zmiana kształtu jest także możliwa poprzez pole magnetyczne lub także dzięki obciążeniu. Możliwości szerszego zastosowania materiałów z pamięcią kształtów otwiera nowe pola generowania czasowych ram przestrzennych dla obiektów kubaturowych, w szczególności dotyczy to struktur wewnętrznych. Materiałem, którego możliwości pobudzają wyobraźnie dla możliwych przestrzeni przyszłości jest stop Ni-Ti. Skład stopów Ni-Ti może zmieniać się od $48 \%$ do $52 \%$ i ma duży wpływ na temperature przemiany fazy wysokotemperaturowej w martenzyt (temperatura ta może zmieniać się od -40 do 100 stopni Celsjusza ). Stopy te posiadają najlepsze właściwości wśród SMA - w polikrysztale można uzyskać odwracalne od- 
kształcenie $8 \%$ i naprężenie przy powrocie do poprzedniego kształtu dochodzące do $800 \mathrm{MPa}$. (Stopy z pamięcią kształtu).

Opisane materiały i zachodzące procesy nie dotyczą rozwiązań materiałowych i projektowych związanych bezpośrednio z obecną technologią budowlaną i realizowanym na dzień dzisiejszy obiektami. Jednakże uzmysławiają nowe możliwości, które rysują się przed projektantami i producentami. Rozwiązania, które są już prawie na wyciągnięcie dłoni. Właśnie żłobki są obiektami, gdzie rysuje się duże pole możliwości zastosowania opisany powyżej materiałów i rozwiązań technologicznych. W szczególności dotyczy to funkcji związanych z edukacją takich jak: rytmika, muzyka ale także funkcji dotyczących rozwoju motorycznego dzieci poprzez zabawę i ruch. Wykorzystując plastyczność w ofertach poszerzamy granice atrakcyjności dla użytkowników, angażując struktury współpracujące przy określonych wzorach użytkowych. Powstałe deformacje i odkształcenia plastyczne oraz możliwość zastosowania materiałów z pamięcią kształtów pozwalają przyjąć rozwiązania projektowe oparte na podziale: szkielet i tkanki miękkie. Podział na dwa współistniejące elementy umożliwia zapewnienie stałego zewnętrznego wydzielenia przestrzennego z plastycznym i podlegającym deformacji zespołem tkanek miękkich będących w bezpośrednim oddziaływaniu wygenerowanych wzorów funkcjonalnych. W dążeniu do realizacji opisanych celów technologia wykonania obiektów oraz proces projektowy powinien ulec ewolucji i zacząć wykorzystywać w szerszym spektrum systemy stosowane przy projektowana np. struktur mechanicznych i automatycznych, których zasada opiera się na wytrzymałym szkielecie nośnym o wielkokierunkowej przestrzeni $\mathrm{i}$ wewnętrznych elementach uzupełniających. Właściwa struktura nośna, odpowiednio sztywna i nieodkształcalna otacza strefy użytkowe o zmiennych parametrach przestrzennych. Przedstawiony powyżej wariant to optymalny schemat, który niestety ze względu na zaawansowanie prowadzonych obecnie badań oraz akceptowalnych kosztów realizacji obiektów jest nieosiągalny. Jednakże nie oznacza to, iż w najbliższej przyszłości nie stanie się standardem w projektowaniu budynków edukacyjnych. W przedstawionym zagadnieniu plastyczność w budynku żłobka koncentrować będzie się głównie na pomieszczeniu oddziału. Oparta zostanie na dwóch głównych aspektach. Pierwszy to wielofunkcyjność charakteryzująca się brakiem konieczności zapewnienia w sali oddziału stałych, niezależnych, elementów wyposażenia przypisanych do określonych funkcji (taniec, rytmika, czytanie, projekcja obrazu) Elementy struktury przestrzennej będą mogły pełnić różnorakie funkcje w zależności od chwilowych oczekiwań. Drugi to płynność, która będzie zmianą wynikłą z aktualnych potrzeb związanych z edukacją oraz możliwą samodzielną kreację dziecka w ramach kierunkowych działań. Umowna płynność zapewni szerokie spektrum interakcji od ruchomych struktur przestrzennych, poruszających się w rytm muzyki, poprzez aksamitne i akustyczne przegrody, gdy oczekiwana jest potrzeba wyciszenia i odpoczynku, aż do projekcji przestrzennych obrazów i kształtów w przypadku działań doświadczalnych.

\section{LUSTRA OTOCZENIA - SYMULATORY}

Symulatory demonstrują zjawiska zachodzące w otoczeniu w wyniku powstających funkcji lub celowych działań uczestników procesu badawczego. Poprzez zastosowanie wielotorowych rozwiązań powstała możliwość wzbogacenia impulsów poznawczych niezbędnych w celu rozwoju nie tylko zainteresowań ale także rozwoju fizycznym dziecka. Działalność nowoczesnych symulatorów nie powinna izolować dziecka od rzeczywistego środowiska oraz minimalizować jego socjalizację. Główny priorytet to wzbudzenie zaciekawienia oraz wygenerowanie potrzeby współpracy pomiędzy dziećmi, zarówno w pracach celowych jak i swobodnej zabawie. Obecnie możemy wykorzystać rozwiązania techniczne, które nie ograniczają się do jednostkowej obsługi użytkowej lecz mogą zapewnić udział w symulacji grupie uczestników. Są to urządzenia pracujące w schemacie systemu rozproszonego oparte na projekcji obrazu i dźwięku przestrzennego. W celu wzmocnienia przekazu i odbioru poza urządzeniami, o bardzo dużych mocach przeliczeniowych, niezbędne jest awangardowe oprogramowanie, które wychodzi poza typowy szablon działania. Oprogramowanie zapewnia nie tylko symulacje cykliczną ale również jest oprogramowaniem kroczącym tzn. adaptującym się do nowych funkcji, które nie zawsze musza się powtarzać w tych samych szablonach. W ten sposób powstaje połączenie mocy obliczeniowej $z$ funkcjami programów. Istotnym parametrem w oprogramowaniu jest współczynnik symulacji poprzedzającej, którego błędne założenia 
mogą niwelować wytyczne użytkowe i oczekiwania osób uczestniczących w funkcji. Tym samym proces poznaczy jest dużo głębszy i bardziej wydajny albowiem poza symulacją celową pobudzana jest wzajemna interakcja uczestników w odpowiedzi na powstałe bodźce. Powstałe w ten sposób interakcje mogą być kierunkowe lub spontaniczne. Obecnie nie ma przeciwskazań dla zastosowania symulatorów w obiektach edukacyjnych w oparciu o adaptacje i rozwinięcie technologii symulacji stosowanych w szeroki spektrum np. orientację poznawczą i poruszanie się w terenie poprzez symulacje rzeczywistej wędrówki (np. przez las o różnych porach roku). Demonstracja może być realizowana poprzez obraz za pośrednictwem projektora laserowego o wysokiej rozdzielczości oraz lustra sferycznego FSR. W celu zapewnienia efektu otoczenia i uzyskania poczucia odbioru wirtualnej przestrzeni stosuje się wyświetlacz sferyczny. Uzupełnieniem są elementy nagłośnienia oraz elementy wyposażenia np. posadzka transmisyjna, fotel itp. Innym rozwiązaniem jest oparcie się na wyświetlaczu sferycznym i kopule wykonanej z kompozytów GRP. Projekcja wielokanałowa odbywa się w paśmie widzialnym oraz w NVG i realizowana jest za pośrednictwem profesjonalnych projektorów instalacyjnych przeznaczonych dla symulacji $7 / 24$. Uzupełnieniem rozwiązania jest optyka hemisferyczna HR. Idąc dalej w poszukiwaniu optymalnych rozwiązań poprzez zastosowanie monitorów autostereoskopowych 3D, w technologii Ultra-D MultiView, które umożliwiają oglądanie obrazów 3D bezpośrednio, możemy wyeliminować konieczność używania okularów 3D co jest bardzo istotne w przypadku starszych dzieci uczęszczających do żłobków. Technologia Ultra-D generuje światło absorbujące ludzką percepcję głębi w sposób zbliżony do rzeczywistego, trójwymiarowego świata. Rozwiązanie optyczne Ultra-D bazuje na dwóch fundamentalnych wskazówkach dotyczącymi głębi. Są to: "stereopsis" oraz częściowa paralaksa ruchu. Daje to bardziej naturalne wrażenia 3D. W Ultra-D nie musimy już poszukiwać „najlepszych” kątów obserwacji obrazu 3D, tak jak to dzieje się w technologii lenticularnej czy bariery paralaksy. Mamy je z dowolnej pozycji - bez ograniczeń ${ }^{8}$

Rozwiązania związane z symulatorami mogą być szeroko stosowane w obiektach edukacyjnych o funkcji żłobka. Na dzień dzisiejszy zakres stosowania ograniczony jest $z$ jednej strony względami finansowymi z drugiej zaś nieufnością rodziców i opiekunów do nowych technologii. Wobec powyższego najczęściej w salach oddziałów żłobkowych stosuje się interaktywne pomoce dydaktyczne w postaci „magicznego dywanu” służących do dedykowanych ćwiczeń, gier i zabaw ruchowych. Magiczny dywan umożliwia w ograniczonym zakresie poprzez różne gry i zabawy rozwój motoryki, koordynacje wzrokowo-ruchową (ryc.4). Równocześnie opisane powyżej symulatory posiadają dwie główne wady. Pierwsza wada dotyczy konieczności zapewnienia stałych elementów przestrzennych o określonych parametrach i lokalizacjach. Elementy opisane powyżej mogą pełnić tylko określone funkcje w zadanych parametrach granicznych. Tym samym ich zdolność adaptacyjna do zapewnienia wielostrumieniowego zapotrzebowania na odmienne funkcje jest mocno ograniczona. Druga wada dotyczy ograniczenia lub nawet pozbawienia fizycznego kontaktu z przyrodą i otoczeniem. Równocześnie symulatory pobudzając ciekawość użytkowników ale w całkowitym oderwaniu od rzeczywistych warunków. Doświadczenia „życiowe” dzieci powstają w sterylnych warunkach bez świadomości działań ubocznych w wyniku powstałych eksploracji.

\section{DŹWIĘK}

Bezpieczeństwo w żłobku nie ogranicza się tylko w niwelacji stresu rozłąkowego dziecka z rodzicem lub opiekunem. Powinno także wyrażać się w prawidłowej organizacji przestrzeni, dobór zabawek ale także poprzez redukcje niepotrzebnych lub działających negatywnie bodźców. Dlatego wymagane są dedykowane metody prac z dzieckiem zwiększające jego aktywności i możliwość samodzielnej zabawy i interakcji z rówieśnikami. Ze względu na ograniczoną samodzielność dzieci w żłobkach konieczny jest także udział opiekunów wykazujących się wysoką empatią, wrażliwością oraz cierpliwością. Współdziałanie pomiędzy potrzebą samodzielności a konsekwentnym i empatycznym wsparciem wytwarza atmosferę gdy aktywność i motywacja do działania są naturalnymi potrzebami dla dzieci. Zwiększają się praktyczne umiejętności a wraz z rozwojem następuje poszerzenie horyzontu zaciekawienia i potrzeby badania. Jednym z elementów badań jest muzyka

\footnotetext{
${ }^{8}$ Na podstawie materiały i produktów firmy Delta sp. j. Krentowski, Hus Białystko.
} 
i dźwięki o różnej intensywności i natężeniu. Głównym elementem wieku niemowlęcego i poniemowlęcego jest kołysanka. Kołysanka to atrybut wczesnego dzieciństwa, utwór muzyczny charakteryzujący się wolnym tempem, służy do uspokojenia, wyciszenia pobudzonego dziecka. (Sadowska 2016 s.247). W trakcie słuchania kołysanki poprzez powtarzające się rytmicznie zwroty muzyczne następuje przyswajanie określonych struktura a ruch kołysania dodatkowa scala doświadczenia rytmu muzycznego z ruchem ciała. Ale kołysanka to nie jedyny element muzycznych, który pozwala dziecku na realizacje własnych poszukiwań i nabywania tym samym nowych doświadczeń. Dźwięki połączone z możliwością poznawania i odkrywania nowych przedmiotów oraz przestrzeni to poszerzenie informacji o otaczającym środowisku. To także rozwój motoryki od rytmicznego klaskani, tupania poprzez improwizacje w użyciu różnych zabawek lub prostych instrumentów muzycznych (grzechotka, bębenek). Aby zapewnić dziecku edukacje muzyczną, należy zwrócić uwagę na planowanie przestrzeni otaczającej dziecko.(Sadowska 2016 s.249). Powstała przestrzeń dzieli się na strefy o różnych zadaniach i funkcjach przy równoczesnym zachowaniu pełnej zmienności dostosowanej do aktualnych potrzeb lub wyzwań. W przestrzeni nie ma martwych struktur, które tworzą tylko funkcjonalne „dekoracje”. Jednym z nowych wymiarów jest dźwięk i jego odbicie w materiale o zmiennej plastyczności. Pojawiające się w przestrzeni utwory i struktury muzyczne pozbawione są uwypuklonej rytmiki $z$ aksamitną barwą instrumentalną. Elementy składowe połączone z niewielkim natężeniem dźwięku są najbardziej właściwymi cząstkami dla aktywizacji muzycznej. Uzupełniają potrzeby zaspokojenia własnej ekspresji. Dźwięk współdziałający z ruchem dodatkowo wzmacnia możliwości poznawcze przedmiotów, struktur przestrzennych (faktur) oraz funkcji występujących w otaczającym go środowisku. Rozwój dziecka zintegrowany jest z piosenką, aktywnością fizyczną do muzyki, powtarzalnymi czynnościami w rytmie inspirowanym dźwiękiem. Muzyka na charakter nie tylko edukacyjny ale także obejmuje obszary tzw. codziennej aktywności dziecka, symulując jego rozwój oraz pogłębiają socjalizację z innym dziećmi w trakcie wspólnych działań.

\section{WNIOSKI}

W poszukiwaniu przestrzeni idealnej wyobraźmy sobie prelekcyjna przestrzeń wydzielona strukturami. Pierwszy odbiór sugeruje nam, iż przestrzeń jest stałym elementem posiadającym typowe punkty charakterystyczne w postaci: otworów, podłóg i stropów. Znajdujemy się w dobrze nam znanym i „oswojonym” „pudełku”. Tymczasem jest to dynamiczna struktura zastygła w oczekiwaniu na wytyczne użytkowe i wyniki funkcji, które będą przebiegać i powstawać w przestrzeni. Zmienność struktury przestrzennej może rozwijać się w wielu kierunkach:

- zmiany kubatury wewnętrznej;

- zmiany struktury materiałowej;

- zmiany atmosfery pomieszczenia.

Zmiana kubatury wewnętrznej polega na dostosowaniu się do oczekiwanych rezultatów w wyniku zadanych funkcji. Zmiana przygotowuje do nowych wydarzeń, które są planowane w określonym przedziale czasowym. Ze względów założeń funkcjonalnych struktura posiada parametry zmienności plastycznej, gwarantującej powrót do pierwotnych parametrów wyjściowych oraz do nowych wytycznych. Zmiana struktury materiałowej dostosowana jest do czasowych potrzeb edukacyjnych i poznawczych. Materiał przyjmuje strukturę o skrajnie różnych parametrach od elementów zintegrowanych z muzyką, poruszających się w rytmie dźwięków, poprzez powierzchnie od chropowatych do perforowanych. Plastyczność materiałowa umożliwia także prowadzenie różnych zajęci dla których parametry akustyczne czy też sterylności higienicznej wymagają obecnie specjalistycznych wykończeni. Nagle w tym samym pomieszczeniu oddziału mogą odbywać się przestrzennej projekcie filmowe, wydarzenia muzyczne połączone $z$ tańcem ale także działania plastyczne związane z swobodną kreacją przestrzeni (np. malowidła ścienne). Połączenie dwóch aspektów związanych ze zmianą plastyczną uwalnia nieograniczony potencjał twórczy nie tylko w zakresie możliwości kreacji projektowej ale w główniej mierze zaspokajania potrzeb użytkowych. Jest także dodatkowym tłem dla zmian związanych z ulotną atmosferą chwili. To okazja do uzyskania przez użytkowników subiektywnego odczucia przebywania w zadaniowych obszarach. Wpływ na to mają nie tylko zmienne parametry przestrzenne i materiałowe ale także wytworzone warunki fizyczne pobudzają- 
ce zmysły np. powonienia, dotyku. Jednym słowem bezpośredniej fizycznej interakcji w funkcji poznawczej. Nowe możliwości projektowe, technologiczne i materiałowe są wsparciem i odbiciem przewidywanych aktywności dzieci w żłobku. Zmienne struktury wraz z ofertami uczestniczą w rozwoju zdolności postrzegania otoczenia przez dzieci. Pomagają w pozyskiwaniu nowych informacji przez dzieci ale także są źródłem obiektywnych danych zachowań dzieci niezbędnych do ciągłego dostosowania programu opiekuńczego i edukacyjnego. Powstają wzory stymulujące: zabawę, ruch, mowę, dotyk, samorealizację, poprzez: adaptacyjną przestrzeń zorientowaną na dziecko (radosne i poważne), dynamiczne aranżacje kreowane we współpracy z dziećmi i w odpowiedzi na oczekiwania dziecka, oferty o różnym charakterze wykorzystujące stymulatory, obszary adaptacji do czasowych potrzeb i wyzwań, kontrolowane zmiany kontekstu i planowanych interakcji, dynamiczne strefy ekspresyjne z mobilnym wyposażeniem. Współtworzy się żywa pracownia zawierająca wieloformatowe elementy istotne dla prawidłowego rozwoju użytkownika. Równocześnie to wyzwanie, które wprowadza projektowanie na nowy poziom. W celu spełniania opisanych powyżej zagadnień konieczna jest całkowita zmiana systemu projektowania, przejścia ze statycznych obiektów do dynamicznych form i ofert, zapewnienie możliwości rozwoju w bezpiecznym otoczeniu którego priorytet zawarty jest w programach edukacyjnych. Schemat projektowy powinien uwzględniać nie tylko rozwiązania projektowe dostępne na dzień dzisiejszy ale także zapewnić możliwość wprowadzenia, w niedalekiej przyszłości, elementów przestrzennych związanych z plastycznością materiału. Dlatego struktura obiektu powinna być na tyle elastyczna i mobilna aby zapewnić zmienność w odpowiedzi na nowe oczekiwania i wyzwania. Tym samym powstaje schemat oparty na sztywnym, komórkowym szkielecie wokół którego powstają miękkie tkanki o zmiennych parametrach użytkowych i przestrzennych. Niezależne od szkieletu tkanki mogą podlegać wymianie na bardziej zaawansowane technologicznie. Wobec powyższego główne zadanie projektanta powinno polegać nie tylko na syntezie obowiązujących przepisy prawa budowalnego i możliwości technicznych ale także na poszukiwaniu uniwersalnych schematów przestrzennych. Schematy są przestrzenią dla wzorów funkcjonalnych wspartych nowoczesnymi materiałami i technologiami w odpowiedzi na możliwe wyzwania użytkowe dla budynków żłobkowych. Dlatego istotne jest aby każde rozwiązanie projektowe poprzedzone było analizą przewidywanych wydarzeń zachodzących w danej strukturze przestrzennej wspartych zarówno technologią jak i programem edukacyjnym. W celu spełniania tego aspektu niezbędne są wielopłaszczyznowe konsultacje zarówno z Inwestorem jak i kadrą pedagogiczną, która będzie jednym z głównych składowych żłobka. Istotnym elementem jest zwrócenie uwagi, iż nie wszystkie dostępne obecnie technologie są w $100 \%$ bezpieczne dla użytkownika lub ich koszt jest adekwatny do oferty i możliwość racjonalnego wykorzystania. W szczególności dotyczy to zarówno nanotechnologii jak i rozbudowanym symulatorów. Opisywane rozwiązania są o tyle istotne, iż na terenach wiejskich nie ma praktycznie dostępu do placówek opiekuńczych dla małych dzieci, co może stanowić barierę w niwelowaniu różnic w poziomie edukacji pomiędzy obszarami wiejskimi i miejskimi. (Piętka-Kosińska i in. 2010 s44). Zwiększenie atrakcyjności miejsca wsparte programami edukacyjnymi może wpłynąć na nowe postrzeganie budynków żłobków. 


\section{BIBLIOGRAFIA}

Bayat Hydayatullah, Rogoża Agnieszka, Ubysz Andrzej: Doświadczalne wyznaczanie trwałych i sprężystych deformacji w zginanych belkach z betonu wysokiej wytrzymałości - Miesięcznik Materiały Budowalne nr 507 11/2014.

Delta sp. j. Krentowski, Hus Białystko ; https://delta-av.com.pl/ dostęp/access 2020-10-06.

Foltynowicz Zenon, Czajka Bogdan, Maranda Andrzej, Wachowski Leszek: Aspekty nanomateriałów w zastosowaniach cywilnych i militarnych. Cześć 2 . Wykorzystanie i obawy wynikające z ich uwalniania do środowiska przyrodniczego. Materiały Wysokoeneretyczne 2017, 9,18-39 Instytut Przemysłu Organicznego 2017.

Gibson, E. J. Exploratory behavior in the development of perceiving, acting, and the acquiring of knowledge. Annual Review of Psychology 1988 s1-41.

Glassolutions Polska https://glassolutions.pl/pl dostęp/access 2020-10-06

Gronostajski Zbigniew, Kuziak Roman: Metalurgiczne, technologiczne i funkcjonalne podstawy zaawansowanych wysokowytrzymałych stali dla przemysłu motoryzacyjnego - Prace IMŻ 1, 2010. Politechnika Wrocławska 2010.

Hornowska Elżbieta, Brzezińska Anna I., Appelt Karolina, Kaliszewska-Czeremska Katarzyna: Rola środowiska w rozwoju małego dziecka - metody badania. Wydawnictwo Naukowe Scholar spółka z o.o. 2014.

Jasiński Marcin: Bezpieczeństwo stosowania nanomateriałów. Instytut Techniki Uniwersytet Pedagogiczny im. KEN w Krakowie. 2018 VI, 2018, s.519-534.

Jemioło Stanisław, Szwed Aleksandra: Deformacje i wytrzymałość materiałów i elementów konstrukcji - Wydział Inżynierii Politechniki Warszawskiej, Oficyna Wydawnicza PW Warszawa 2013.

Zeszyt 12/2012, 2012 Komisja Inżynierii budowlanej Oddział Polskiej Akademii Nauk w Katowicach s25-28.

Kłoskowicz Małgorzata: Zachwycać się czy wstrzymać oddech? Oddzialywaie nanocząstek na organizmy żywe. Oddziaływanie nanocząstek na organizmy. Badania prof. Marii Augustyniak - Gazeta Uniwersytecka UŚ nr 6(276) s. 16-17 marzec 2020.

Mackiewicz Bogna, Szczepkowska-Szczęśniak Katarzyna: Znaczenie otoczenia w wychowaniu. Federacja Inicjatyw Oświatowych. Małe Przedszkole w Każdej Wsi. https://www.fio.org.pl/ dostęp/access 2020-10-06.

Stopy z pamięcią kształtu http://www.matint.pl/materialy-z-pamiecia-ksztaltu.php dostęp/access 2020-10-06.

Myga-Piątek Urszula, Jankowski Grzegorz: Wpływ turystyki na środowiska przyrodnicze i krajobraz kulturowy - analiza wybranych przykładów obszarów górskich. Problemy Ekologii Krajobrazu T.XXV.27-38 Wydział Nauk o Ziemi Uniwersytet Śląski 2009.

Piętka-Kosińska Katarzyna, Ruzik-Sierdzińska Anna; Żłobki w Polsce Badania empiryczne i jakościowe. Badanie przeprowadzone w 2010r na zlecenie Banku Światowego przy współpracy merytorycznej Departamentu Polityki Rodzinnej MPiPS, Warszawa X.2010.

Sadowska Katarzyna: Żłobek jako miejsce fundamentalnej edukacji muzycznej małego dziecka - Zakład Edukacja Elementarnej i Terapii Pedagogicznej Wydz. Studiów Edukacyjnych UAM w Poznaniu 2016 s. 239-254.

Szymczak Tadeusz, Kowalewski Zbigniew L.: Laboratoryjne symulacje obciążeń cyklicznych determinujących zmiany właściwości mechanicznych materiałów konstrukcyjnych - zeszyt 7-8/2006 Rok wyd. LXV Instytut Podstawowych Problemów Techniki PAN 2006.

Telka Lucyna: Przekształcanie przestrzeni społecznej placówki. Studium społeczno-pedagogiczne na przykładzie żłobków, Wydawnictwo Uniwersytetu Łódzkiego 2009.

Wygotski Lew: Wczesne dzieciństwo, wybrane prace psychologiczne II dzieciństwo i dorastanie Wyd. Zysk i S-ka. 2020

\section{ABOUT AUTHOR}

A graduate of the Cracow University of Technology, the Faculty of Architecture, gained experience in execution and design in many companies. Specialization in the design of service and public facilities, educational buildings in particular. A laureate of numerous architectural competitions. Running his own design practice since 2001. 


\section{O AUTORZE}

Absolwent Politechniki Krakowskiej, Wydziału Architektury. Doświadczenie wykonawcze i projektowe zdobył w wielu firmach. Specjalizacja w projektach obiektów usługowych i użyteczności publicznej w szczególności budynków edukacyjnych. Laureat licznych konkursów architektonicznych. Od 2001 roku prowadzi własną praktykę projektową.

Contact | Kontakt: szumielewicz@sscarchitekci.pl 